\title{
A2 milk: a new way to offer a flat white?
}

\section{Lindsay Neill and Guo Jingsi}

Dr Lindsay Neill is a senior lecturer in hospitality management at AUT. Lindsay holds research interests in vernacular culture, food, identity, and popular culture.

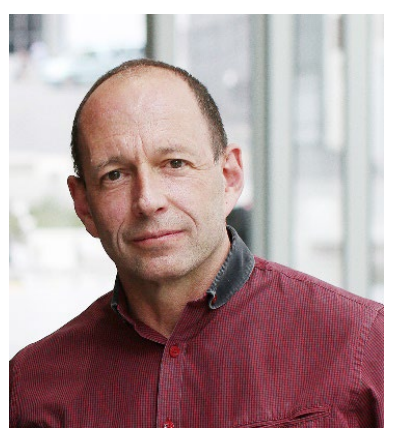

Guo Jingsi has recently completed a Master of Gastronomy qualification at AUT University, studying the impact of A2 milk within Aotearoa New Zealand's coffee and café culture. This is her first foray into academic publishing.
This research sought feedback from professional baristas on their views and experiences of A2 milk use in café coffee production. Their views are important because Aotearoa New Zealand prides itself on its unique café and coffee culture. Reflecting that, in the 1940s, it was observed that for American tourists visiting Auckland, the coffee offered at the White Lady pie cart was an almost compulsory experience [1]. Key to that experience was the White Lady's coffeemaking Goldie Convection Tripolator. Coffee making technologies and ingredients have changed since those times, including the diversity of milks used in espresso milk-based coffees. Today, four milks dominate café and coffee culture in Aotearoa New Zealand (Table 1).

Table 1. The four most popular milks used in coffee making in Aotearoa [2]

\begin{tabular}{lc}
\hline Type of milk & \multicolumn{1}{c}{ Benefit/description } \\
\hline Full cream milk & $\begin{array}{r}\text { Full-cream cow's milk that it comparatively high in fat and } \\
\text { calorie content. }\end{array}$ \\
Skim milk & $\begin{array}{r}\text { Fat-free cow's milk. Popular with consumers who are trying to } \\
\text { manage their weight and/or avoid fat in their diets. } \\
\text { Made from soybeans. Soy milk is a popular alternative to } \\
\text { animal milk. }\end{array}$ \\
Almond milk & $\begin{array}{c}\text { Made from almonds. Popular with consumers who wish to } \\
\text { avoid the fat found in cow's milk. }\end{array}$ \\
\hline
\end{tabular}

Those top four milks are complemented by a further wide range of non-dairy milks (Table 2).

However, Tables 1 and 2 fail to list one milk that is popular in Aotearoa New Zealand: A2 milk. Our interest in A2 milk aligns it with another Kiwi icon, the flat white. We ask, why are baristas not offering A2 milk in our cafés as another signifier of Kiwi innovation, uniqueness, and identity? Within that notion our inquiry is an important consideration for café operators and others serving coffee, to create a unique 'Kiwi' point of difference in what can be otherwise described as a homogenised coffee marketplace.

In 'discovering' A2 milk, Dr Corran McLachlan observed that ordinary cow's milk contained two major casein (or protein) types - A1 and A2 - but that some cows do not produce A1. He then developed a method to identify milk that only contained the A2 protein. From that development, in 2018 the a2 Milk Company partnered with Fonterra, New Zealand's largest dairy co-operative 
[4]. Today, A2 milk products have a $11.2 \%$ share of the New Zealand milk market [4].

Table 2. Non-dairy milks available in New Zealand [3]

\begin{tabular}{|c|c|}
\hline Type of milk & Description \\
\hline Coconut milk & $\begin{array}{l}\text { Made by blending coconut flesh. Full-fat coconut milk is high } \\
\text { in calories. }\end{array}$ \\
\hline Almond milk & A mixture of finely ground almonds and water. \\
\hline Soy milk & $\begin{array}{l}\text { Made by grinding soybeans. A source of protein and essential } \\
\text { fatty acids. }\end{array}$ \\
\hline Oat milk & A cereal grain derived milk made by grinding oats. \\
\hline Rice milk & Milled white or brown rice and water. \\
\hline Cashew milk & A mixture of cashew nuts or cashew butter and water. \\
\hline Macadamia milk & A combination of water and about $3 \%$ macadamia nuts. \\
\hline Hemp milk & Ground seeds of the hemp plant, Cannabis sativa, and water. \\
\hline Quinoa milk & Made from water and quinoa. \\
\hline Seven-grain milk & $\begin{array}{l}\text { A combination of oats, rice, wheat, barley, triticale, spelt, } \\
\text { millet and water. }\end{array}$ \\
\hline
\end{tabular}

To explore the use of A2 milk, we asked five baristas, with an average career span of 25 years, their views on using A2 milk for making coffee. We were surprised by the results.

Firstly, our participant baristas looked overseas for their inspiration. Exemplifying that was their interest in latte art and nitrogen infused coffees. Interestingly, our participants held a cautious 'wait and see' attitude toward using A2 milk, despite their embrace of many of the milk types outlined in Tables 1 and 2. While our participants mentioned that they would provide A2 milk should consumers begin asking for it, none of them realised that by offering A2 milk they could self-create a temporary point of difference in an otherwise homogeneous coffee marketplace. Additionally, our participant baristas were waiting for the a2 Milk Company to take the lead and promote the use of A2 milk in Aotearoa New Zealand's café/coffee culture.

Consequently, and while our sample size was small, we wonder if cafés are missing an important opportunity for distinction by not offering A2 milk within their milk menu offerings. We suggest that, by using and showcasing A2 milk, Kiwi cafés can enhance the distinctive reputation they already enjoy and in doing so promote the Kiwi cultural attribute of innovation.

\section{Corresponding author}

Lindsay Neill can be contacted at: lindsay.neill@aut.ac.nz

\section{References}

(1) Neill, L.; Bell, C.; Bryant, T. The Great New Zealand Pie Cart; Hodder Moa: Auckland, 2008.

(2) Hurwood, J. A Guide for the Different Types of Milk, 2016. Canstar Blue New Zealand. https://www.canstarblue.co.nz/food-drink/a-guide-to-different-types-of-

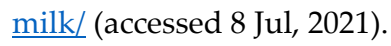

(3) Kundu, P.; Dhankhar, J.; Sharma, A. Development of Non-Dairy Milk: Alternative Using Soymilk and Almond Milk. Current Research in Nutrition and Food Science 2018, 6(1), 203-210. https://doi.org/10.12944/CRNFSJ.6.1.23

(4) a2 Milk Company Home Page. https://a2milk.nz/ (accessed Jul 7, 2021) 